\title{
The (dis)use of the golf landscape in Galicia through the most significant courses
}

Sergio Carballo-Pérez [https://orcid.org/0000-0002-0601-8784]

Architect, PhD student in Architecture and Urbanism, University of A Coruna

ETS Arquitectura, Zapateira, 15071 A Coruna, Spain.

E-mail: sergio.carballo@udc.es

Keywords: golf courses; landscape integration; territory; thermal golf; Galicia;

\begin{abstract}
In the decade of 1960, the first golf courses were built in Galicia. On the one hand, the Golf Club of La Coruna, whose shape is not compact and creates several loops of routes that provide a broad perimeter, a condition that is highly desired by developers (Fernández de Caleya, 2007, p.189). The designers are conditioned by the quantity and disposition of the houses, giving priority to the real estate performance and the views towards the course (Villar Lama \& Fernández Tabales, 2013, p.359). They are inserted in the interstitial spaces derived from the morphological configuration of the course, and although a large part has not been built, it is possible to read the trace of the intentions on the landscape. Seven years later, La Toja Golf Club was born, a model of tourist golf where the design of the course prevails, the number of houses is much smaller and its degree of visual contamination towards the golf course is better treated (Villar Lama \& Fernández Tabales, 2013, p.359).

In the decade of the nineties, the tendency of the interventions that use the golf courses as a transforming element of the landscape in a real estate incentive is reflected in Galicia (Villar Lama, 2011, p.15) with the Ría de Vigo Golf Club, where soil movements have been important (Fernández de Caleya, 2007, p.209), terracing the terrain to generate several levels from which to glimpse the course (Villar lama \& Fernández Tabales, 2013, p.365). These operations are intensified in the first years of the new century in much of our country (Navarro Vera \& Ortuño Padilla, 2013, p.2), while Galicia takes a turn towards a less invasive option: golf spas. Between 2000 and 2006 three courses are executed in Mondariz, Guitiriz and Augas Santas, with similarities in their logic of insertion: presence of a regulated accommodation (hotel) with a dominant position over the rest of the intervention; the topographic conditions of the support terrain are exploited; compact design without interstitial spaces.

Thermal golf ushered in a new phase for Galicia, since the most important interventions of the following years moved away from the American format based on the theory of hedonic prices of the golf landscape for residential areas (Villar Lama \& Fernández Tabales, 2013 , p.358), betting on a more British intervention where the play areas, the natural protection and delimitation areas of the course and even the areas of pastures and adjoining crops are confused in a spatial continuity. In general terms, the foundations have been laid for a new culture of the territory in which there is no talk of a contrast between golf courses and landscape, but rather spaces of opportunity for landscape projects that can reactivate the heritage and cultural values of our society, so the golf landscape in Galicia is still in (dis)use.
\end{abstract}


1. The development of golf courses in Spain: a context with a tourist vocation

Golf was introduced in Spain by a group of British people settled in Gran Canaria, who created in 1891 the Golf Club of Las Palmas. From then until the mid-twentieth century, economic crises, the Civil War and little demand slowed down the construction of courses until the tourist development powers it on the sixties in Mediterranean coastal areas and the metropolitan area of Madrid (Feo Parrondo, 2001, p.57). Since then, the construction of new golf courses is very intense, with a dynamic only interrupted in the 1980s. But from the nineties there is an explosive growth, where almost $70 \%$ of the existing courses have been built in the last two decades (Babinger, 2012, p.186).

During the beginnings of this sport, foreign models were used, which were adapted to the different demands of each region where it was installed, and there was great permissiveness by the different Public Administrations, which contemplated such facilities, initially, with curiosity, to later start to worry about them as a way of tourist attraction (Roca, 1998, p.121). These models represent a type of landscape that is originally from other places, where environmental or climatic conditions are very different (abundance of rainfall and high humidity), which implies an adaptation or a radical transformation of the landscape. In most cases, it has not been the golf course itself or its extension (despite being important) the main transforming element of the landscape, but the impact generated around it: housing developments (Priestley \& Sabí, 1993, p .68).

2. The reflection of real estate golf in Galicia: the landscape as an excuse

Although the pioneer of golf in Galicia is the Aero Club of Vigo with a small project of three fairways and four greens in 1959, the final arrival of this sport is produced with the construction of the Golf Club of La Coruna three years later. It is a parkland-type course designed by Mackenzie Ross, one of those Britons who had settled in Gran Canaria. This data may seem irrelevant, but it is not, since there is a temporary coincidence in the design process of three golf courses by the same architect. Therefore, the type of layout and the model of implantation that would be used in A Coruña would correspond in a high percentage to the one that was being carried out on the island. In fact, the shape of all three of them is not compact and creates several loops of routes that provide a wide perimeter, a condition that is highly desired by developers (Fernández de Caleya, 2007, p.189). The designer is conditioned by the quantity and arrangement of the houses, giving priority to the real estate performance and the views towards the course (Villar Lama \& Fernández Tabales, 2013, p.359). They are inserted in the interstitial spaces derived from the morphological configuration of the course, and although a large part of the projected houses has not been built, the material trace of the intentions on the landscape can be read. Through its transformation into a golf course, the landscape gives a new added value to real estate development when it is forced to move away from the first coast line, "substituting the blue of the sea for the green of the green" (Aledo Tur, 2008, p.105). 

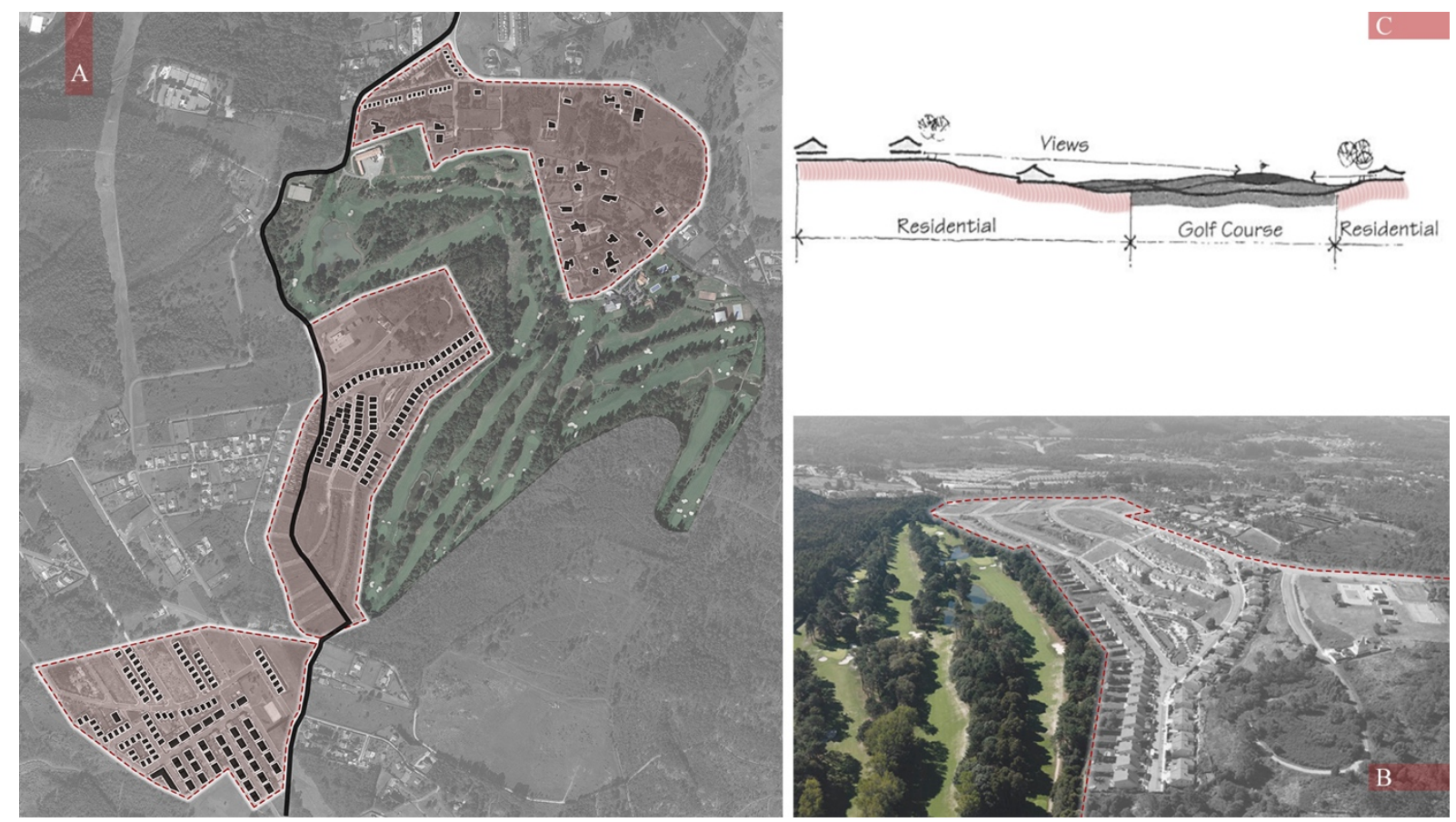

Fig. 1 (A) - Golf Club of La Coruña in 2019 // Source: Google Earth. Own elaboration.

Fig. 1 (B) - Own elaboration from Fernández, C. (2019). [Figure]. Recovered from: https://bit.ly/2EKiy2F Fig. 1 (C) - Own elaboration from Murhead, D. \& Rando, G. (1994). Views of the golf course from low-rise buildings. [Figure]

In 1969, the La Toja Golf Club was created, whose course shape creates a single loop that borders a pine forest centre (Fernández de Caleya, 2007, p.205). It is a model of tourist golf, which unlike the previous one, the design and the correct management of the course prevail, the number of houses is much lower and its degree of visual pollution towards the course is better treated (Villar Lama \& Fernández Tabales, 2013, p.359). It is located on the island that gives its name to the course, used for centuries as a place of grazing by the neighbours of El Grove, a town to which it is linked by a nineteenth-century bridge. It resembles the resort typology, which has been imposing changes in the cultural and landscape identity of many places in our country. Thus, the identity of belonging to a land with its history and its use of the territory is giving way to a heterogeneous community of a foreign spatial model. The common spaces give way to private and exclusive spaces, segregated from their surroundings, which in the Anglo-Saxon world is called gated communities (Babinger, 2012, p.194). In addition, this phenomenon formally materializes in this case through the aforementioned bridge.

In the following decades, there are no excessive constructions of new plant courses in Galicia, but during the seventies, those that stand on plains near the airports of Santiago and Vigo stand out. They are courses with a surface around 20-25 hectares for nine holes and whose land is very devalued, both for the second residence and for certain tree plantations (Fernández de Caleya, 2007, p.202). 

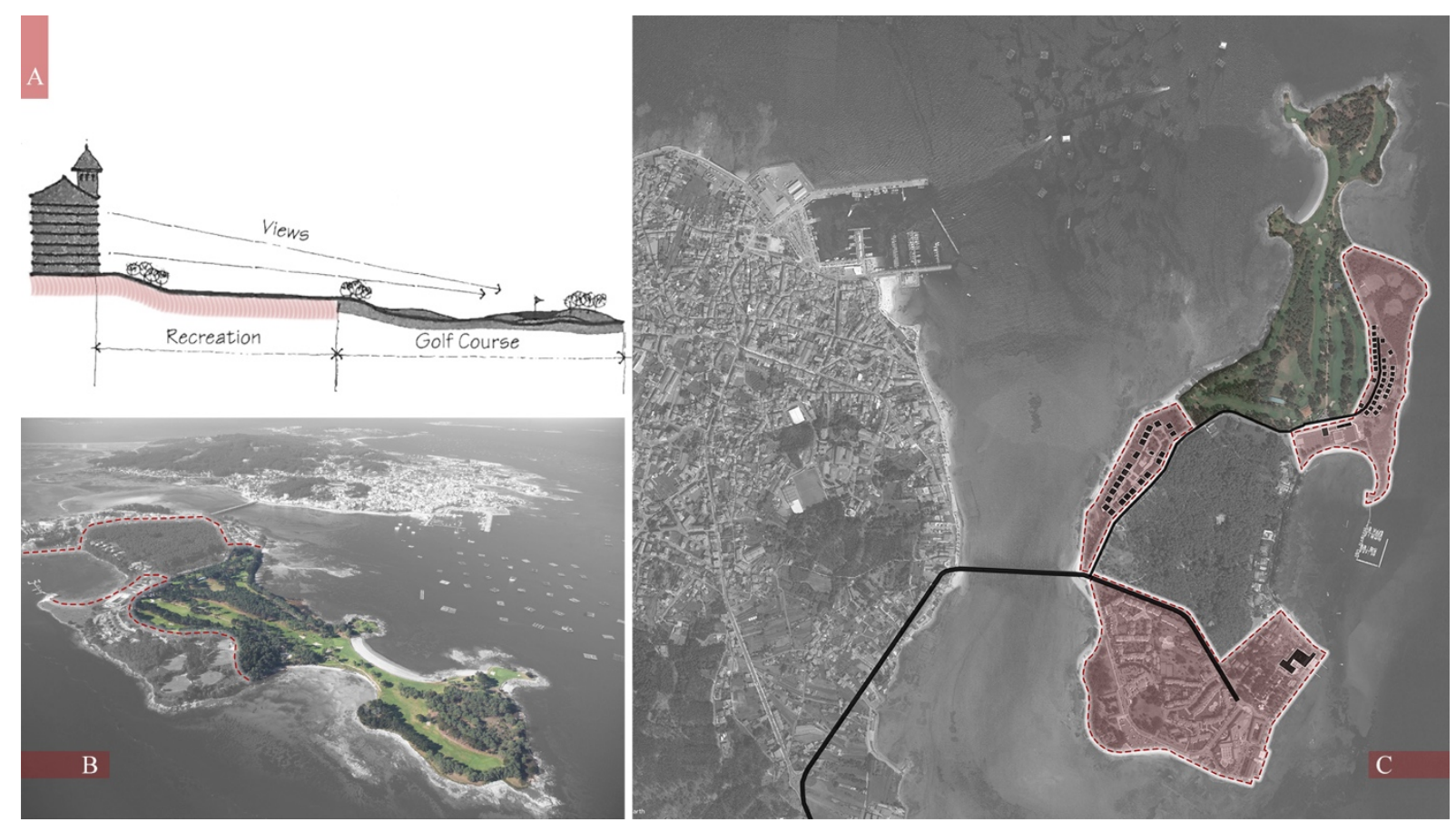

Fig. 2 (A) - Own elaboration from Murhead, D. \& Rando, G. (1994). Views of the golf course from a high-rise building. [Figure]

Fig. 2 (B) - Own elaboration from [La Toja Island]. Recovered from: https://bit.ly/2WEzVfu

Fig. 2 (C) - La Toja Golf Club in 2019 // Source: Google Earth. Own elaboration.

3. The golf of the spas: the rural landscape as a tourist alternative

During the nineties, the phenomenon of large residential operations developed around golf courses emerged in Spain (Navarro Vera \& Ortuño Padilla, 2013, p.2). A reflection of this trend also occurs in Galicia with the construction of the Ría de Vigo Golf Club in 1993, where soil movements have been important and economically debatable (Fernández de Caleya, 2007, p.209). Its layout is compact, does not generate interstitial areas, and even so it is possible to appreciate the intention of using the terrain topographically, building terraces to generate several levels from which to glimpse the golf course (Villar Lama \& Fernández Tabales, 2013, p.365). This type of interventions that use golf courses as a transforming element of the landscape in a real estate incentive (Villar Lama, 2011, p.15), intensify in the first years of the new century in a large part of our country.

However, during these years, Galicia takes a turn towards a less invasive option: golf spas. After the success achieved with the intervention in La Toja, positioning the spa there among one of the most important in the country, the first thermal operation of the new century is executed in 2000 in Mondariz. Three years later, the Spa of Guitiriz reopens its doors after being closed in 1972, but this time it would count among its ranks with a nine-hole golf course. Already in 2006, and following the line of the previous interventions, a spa of new plant is built in the municipality of Pantón. These pieces have similarities in their logic of insertion: presence of a regulated accommodation (hotel) with dominant position over the rest of the intervention; the topographic conditions of the support terrain are exploited; and the layout is compact without interstitial spaces. 
There are critical authors with this type of operations in rural nuclei, as is the case of Fourneau (1998, p.53), who affirms that "they are foreign bodies implanted in the rural space for urban people who seek outdoor entertainments, but not far from a highway, and with little interest for the activity, culture and landscape of the rural world ". On the other hand, other authors (Gómez-Lama López, Priego de Montiano, Recio Espejo \& Berbel Vecino, 1994) make indications about landscape improvement and the integration in the environment of golf courses located in areas that have little agricultural value due to poverty and poor development of the soil, the current state of degradation or its complicated physiography. In the specific case of the courses linked to spas in Galicia, its construction has rekindled anthropized landscapes, involving slight transformations of the primitive form of the area (...) and that have been made to break the plain minimally (Gómez-Lama López et al., 1994).
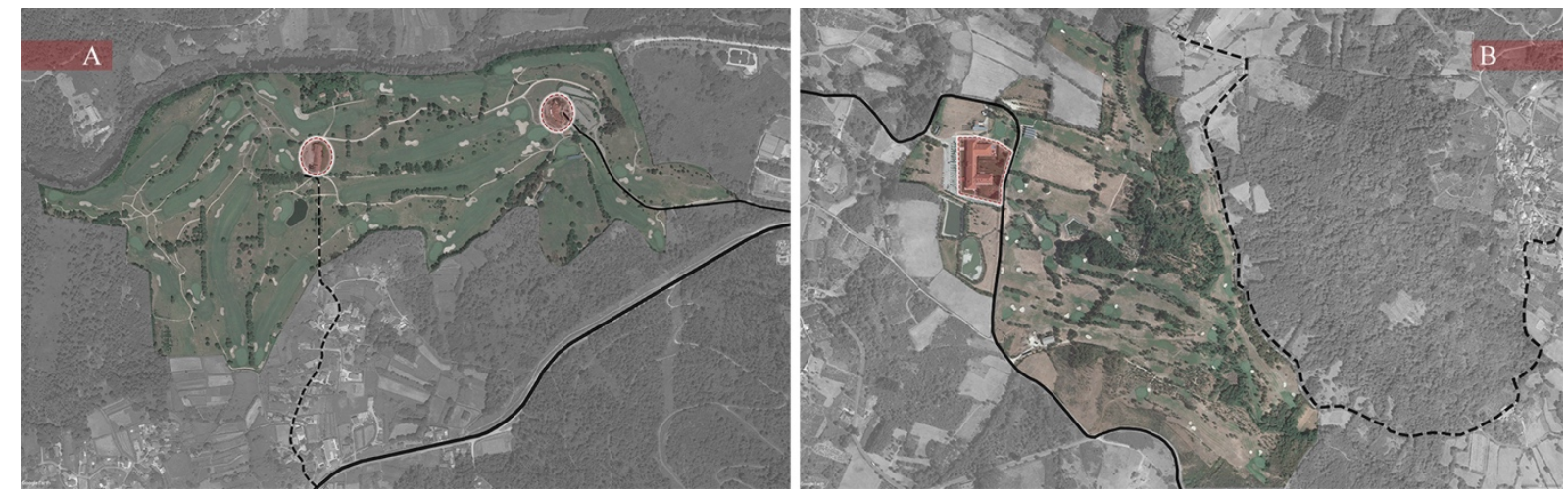

Fig. 3 (A) - Mondariz Spa Golf Club in 2019 // Source: Google Earth. Own elaboration.

Fig. 3 (B) - Augas Santas Spa Golf Club in 2019 // Source: Google Earth. Own elaboration.

\section{Conclusions}

Thermal golf ushered in a new phase for Galicia, since the most important interventions of the following years moved away from the American format based on the theory of hedonic prices of the golf landscape for residential areas (Villar Lama \& Fernández Tabales, 2013, p.358). Galicia has opted for a more British intervention where play areas, natural areas of protection and delimitation of the course and even the areas of pastures and adjacent crops are confused in a spatial continuity. It is worth mentioning the case of the Chan do Fento Golf Club (Pontevedra), the only golf course owned and managed by the Autonomous Community, with a compact layout and extremely respectful with the topography, endemic species and landscape characteristics of the area where it is inserted.

This trend of territorial development of golf courses has continuity nowadays through interventions that have been progressively reducing the consumption of surface at the time of positioning on the territory. In general, the foundations have been laid for a new culture of the territory in which there is no talk of a contrast of golf courses vs. landscape, if not opportunity spaces for landscape projects at different scales, which can reactivate the heritage values and cultural aspects of our society, so that the golf landscape in Galicia is still in (dis)use. 


\section{References}

- Aledo Tur, A. (2008). De la tierra al suelo: la transformación del paisaje y el nuevo turismo residencial. Arbor. Ciencia, Pensamiento y Cultura, CLXXXIV. (N ${ }^{\circ}$ 729), pp. 99-113

- Babinger, F. (2012). El golf en España: la concentración social y territorial de un fenómeno que trasciende ampliamente lo deportivo. Ería: Revista cuatrimestral de geografía, (No 88), pp. 185-197.

- Celles Anibarro, C. (2008). Historia del Golf en España. Sus inicios y desarrollo 18911959. León, España: Editorial Everest.

- Feo Parrondo, F. (2001). Los campos de golf en España y sus repercusiones en el sector turístico. Cuadernos de Turismo. ( $\left.{ }^{\mathrm{o}} 7\right)$, pp. 55-66

- Fernández de Caleya, J. (1997). El diseño de los campos de golf: una aproximación paisajística. (Tesis Doctoral). Universidade da Coruña, A Coruña, España.

- Fernández de Caleya, J. (2007). El diseño de los campos de golf: una aproximación paisajística. Barcelona, España: Munilla-Lería.

- Fourneau, F. (1998). El turismo en el espacio rural en Francia. Cuadernos de Turismo. ( $\left.\mathrm{N}^{\mathrm{o}} 1\right)$, pp. 41-53

- Gómez-Lama López, M., Priego de Montiano, R., Recio Espejo, J. M. \& Berbel Vecino, J. (1994). Valoración ambiental de los campos de golf de Andalucía. Córdoba, Universidad de Córdoba. 142 pp.

- González-Varas Ibáñez, S. (2006). Retos y expectativas urbanísticas en el suelo no urbanizable. El "urbanismo autonómico" (Golf y urbanismo). Revista Jurídica de Castilla y León, ( $\left.\mathrm{N}^{\mathrm{o}} 8\right)$, pp. 107-148

- Navarro Vera, J. R. \& Ortuño Padilla, A. (2013). Golfy territorio: estudio sobre el impacto de los campos de Golf y actuaciones urbanísticas asociadas en la Comunidad Valenciana y la Región de Murcia. Madrid, España: Garceta: Colegio de Ingenieros de Caminos, Canales y Puertos.

- Priestley, G. K. \& Sabí Bonastre, J. (1993). El medio ambiente y el golf en Cataluña: problemas y perspectivas. Documents d'Analisi Geográfica. ( $\left.\mathrm{N}^{\mathrm{o}} 23\right)$, pp. 45-74

- Roca Roca, E. (1998). Campos de golf y ordenación del territorio: régimen jurídico. Revista de Derecho Urbanístico y Medio Ambiente. ( $\left.\mathrm{N}^{\mathrm{o}} 165\right)$, pp. 119-142

- Villar Lama, A. (2011). Territorio, turismo y paisaje: el proceso de urbanización en el litoral de Andalucía. El papel de los campos de golf. (Tesis Doctoral). Universidad de Sevilla, Sevilla, España.

- Villar Lama, A. \& Fernández Tabales, A. (2013). Diagnóstico y perspectiva territorial del golf en Andalucía: entre la cualificación turística y el desarrollismo inmobiliario. Boletín de la Asociación de Geógrafos Españoles. ( ${ }^{\circ}$ 62), pp. 357-378 